\title{
PENGARUH PELATIHAN DAN PROMOSI JABATAN TERHADAP KINERJA KARYAWAN OUTSOURCING DI PT GARUDA INDONESIA (Persero) Tbk
}

\author{
Agus Yulistiyono', Solahudin² \\ Universitas Muhammadiyah Tangerang \\ agus.yulistiyono@gmail.com
}

Keyword

Abstract

employee performance

This study aims to determine: (I) The effect of training on the performance of outsourcing employees at PT Garuda Indonesia (Persero) Tbk, (2) The effect of job promotions on the performance of outsourcing employees at PT Garuda Indonesia (Persero) Tbk, (3) Effects of training and promotion position on the performance of outsourcing employees at PT Garuda Indonesia (Persero) Tbk.The results show that: (I) Training has a positive effect on the performance of outsourcing employees at PT Garuda Indonesia (Persero) Tbk, this can be seen from the results of simple regression analysis that addresses projections the higher the value of training at a certain value, the higher the value employee performance at a certain value (2) job promotion has a positive effect on the performance of outsourcing employees at PT Garuda Indonesia (Persero) Tbk, this can be seen from the results of simple regression analysis that addresses projections the higher the value of promotion at a certain value, the higher also the value of employee performance at $a$ certain value (2) Training and job promotion have a positive effect on the performance of outsourced employees at PT Garuda Indonesia (Persero) Tbk, this can be seen from the results of multiple regression analysis, which proves the higher the value of training and promotion at certain values, mak a the higher the value of employee performance at a certain value 


\section{PENDAHULUAN}

\section{Latar Belakang Masalah}

Pada era globalisasi seperti saat ini setiap perusahaan terus mengalami berbagai masalah yang berkaitan dengan sumber daya manusia, salah satunya adalah minimnya kualitas dan kemampuan yang dimiliki oleh para karyawan. Perusahaan menyadari bahwa sumber daya manusia merupakan modal dasar suatu perusahaan dan juga mempunyai peranan yang sangat penting dalam menentukan keberhasilan suatu perusahaan. Masalah tidak kompetennya karyawan sudah menjadi topik permasalahan yang umum di setiap perusahaan sejak lama. Oleh karena itu kualitas sumber daya manusia harus dikembangkan dan diarahkan untuk meningkatkan efektifitas, efisiensi dan produktifitasnya dalam segala bidang agar tujuan yang telah ditetapkan oleh perusahaan dapat tercapai.

Garuda Indonesia adalah maskapai penerbangan milik pemerintah yang menawarkan layanan full services. Sebagai maskapai pembawa bendera bangsa, saat ini Garuda Indonesia telah melayani lebih dari 90 destinasi di seluruh dunia dan berbagai lokasi eksotis di Indonesia. Dengan jumlah penerbangan mencapai 600 penerbangan perhari, Garuda Indonesia memberikan pelayanan terbaik melalui konsep "Garuda Indonesia Experiences" yang mengedepankan keramahtamahan dan kekayaan budaya khas Indonesia.

\section{Rumusan Masalah}

Masalah merupakan suatu keadaan atau penyimpangan yang terjadi dalam suatu organisasi yang menuntut untuk diadakannya suatu penyelesaian. Maka dalam hal ini rumusan masalah yang diambil oleh peneliti, antara lain :

I. Apakah terdapat pengaruh pelatihan terhadap kinerja karyawan outsourcing?

2. Apakah terdapat pengaruh promosi jabatan terhadap kinerja karyawan outsourcing ?

3. Apakah terdapat pengaruh pelatihan dan promosi jabatan terhadap kinerja karyawan outsourcing?

\section{Tujuan Penelitian}

I. Untuk mengetahui pengaruh pelatihan terhadap kinerja karyawan outsourcing.

2. Untuk mengetahui pengaruh promosi jabatan terhadap kinerja karyawan outsourcing.

3. Untuk mengetahui pengaruh pelatihan dan promosi jabatan terhadap kinerja karyawan outsourcing.

\section{TINJAUAN PUSTAKA}

\section{Kinerja}

Menurut As'ad dalam Sudaryono (2017:67) menyatakan bahwa kinerja merupakan kesuksesan seseorang dalam melaksanakan suatu pekerjaan. Hal ini menjelaskan bahwa kinerja adalah hasil yang dicapai seseorang menurut ukuran yang berlaku untuk pekerjaan yang bersangkutan. Kinerja seseorang dapat terlihat melalui aktifitasnya dalam melaksanakan pekerjaan sehari-hari. Aktifitas ini menggambarkan bagaimana ia berusaha untuk mencapai tujuan yang telah ditetapkan.

Menurut Moeheriono (2012:95), kinerja
atau performance merupakan sebuah
penggambaran mengenai tingkat pencapaian
pelaksanaan suatu program kegiatan atau
kebijakan dalam mewujudkan sasaran, tujuan,
visi dan misi organisasi yang dituangkan dalam
suatu perencanaan strategis suatu organisasi.

Sedangkan menurut Rivai (2013:64), kinerja merupakan suatu istilah secara umum yang digunakan sebagian atau seluruh tindakan atau aktifitas dari suatu organisasi pada suatu periode dengan suatu referensi pada sejumlah standar seperti biaya masa lalu yang diproyeksikan dengan dasar efisiensi, pertanggung jawaban atau akuntabilitas manajemen dan semacamnya.

\section{Pelatihan}

Menurut Kasmir (2016:126) mengatakan pelatihan merupakan proses untuk membentuk dan membekali karyawan dengan menambah keahlian, kemampuan, pengetahuan dan perilakunya. Artinya pelatihan akan membentuk perilaku karyawan yang sesuai dengan yang diharapkan perusahaan, misalnya sesuai dengan 
budaya perusahaan. Kemudian akan membekali karyawan dengan berbagai pengetahuan, kemampuan dan keahlian, sesuai dengan bidang pekerjaannya.

Menurut Widodo (2015:82), pelatihan merupakan serangkaian aktifitas individu dalam meningkatkan keahlian dan pengetahuan secara sistematis sehingga mampu memiliki kinerja yang professional di bidangnya. Sementara itu menurut Andrew F. Sikula dalam R. Supomo (2018:63), pelatihan adalah suatu proses pendidikan jangka pendek dengan menggunakan prosedur yang sistematis dan terorganisasi sehingga karyawan operasional mempelajari pengetahuan teknik pengerjaan dan keahlian untuk tujuan tertentu.

Noe dalam Kasmir (2016:6), menyebutkan training refers to a planned effort by a company to facilitate the learning of jobrelated knowledge, skill and behavior by employees. Berdasarkan pendapat yang dikemukakan oleh Noe tersebut dapat disimpulkan bahwa pelatihan merupakan fasilitas yang disediakan oleh perusahaan untuk mempelajari pekerjaan yang berhubungan dengan pengetahuan, keahlian dan perilaku karyawan. Artinya untuk menambah pengetahuan, keahlian dan perilaku karyawan dapat dilakukan melalui pelatihan yang tentunya sudah direncanakan oleh perusahaan sebelumnya.

\section{Promosi Jabatan}

\section{METODE PENELITIAN}

Pendekatan penelitian yang digunakan adalah dengan metode deskriptif kuantitatif, menurut Sugiyono (2016:8) metode penelitian kuantitatif dapat diartikan sebagai metode penelitian yang berlandaskan pada filsafat positifisme, digunakan untuk meneliti pada populasi atau sampel tertentu, pengumpulan data menggunakan instrumen penelitian, analisis data bersifat kuantitatif atau statistik, dengan tujuan untuk menguji hipotesis yang telah ditetapkan.

\section{Tempat dan Waktu Penelitian}

Penelitian dilakukan di PT Garuda Indonesia (persero) Tbk yang beralamat di Kawasan Perkantoran Garuda Sentra Operasi, Bandara Internasional Soekarno Hatta, Tangerang. Persiapan dan proses penelitian yang
Menurut Hasibuan dalam R. Supomo (20I8:88) menjelaskan promosi adalah perpindahan yang memperbesar authority (wewenang) dan responsibility (tanggung jawab) karyawan ke jabatan yang lebih tinggi dalam suatu organisasi sehingga kewajiban, hak, status, dan penghasilan akan semakin membesar.

Sementara menurut Andrew F. Sikula dalam Eti Nurhayati (20I8:88), secara teknik promosi adalah perpindahan di dalam suatu organisasi dari satu posisi ke posisi lainnya yang melibatkan peningkatan gaji maupun kenaikan status. Lebih lanjut, Samsudin Sadili dalam Eti Nurhayati (2018:88), menjelaskan bahwa promosi adalah perpindahan seseorang di suatu jabatan organisasi dan diberikan kesempatan untuk maju ke jabatan yang lebih tinggi.

Promosi jabatan menurut Ardana (2012:106) adalah suatu proses perubahan dari suatu pekerjaan ke suatau pekerjaan yang lain, pada hierarki wewenang dan tanggung jawab yang lebih tinggi dibandingkan dengan wewenang dan tanggung jawab yang telah dibebankan kepada diri karyawan pada waktu sebelumnya. Menurut Siagian (2014:140), menyatakan promosi jabatan adalah perpindahan pegawai dari satu pekerjaan ke pekerjaaan lain yang tanggung jawabnya lebih besar, tingkatan hirarki jabatannya lebih tinggi dan penghasilannya pun lebih tinggi pula.

peneliti lakukan terhitung mulai bulan April sampai dengan bulan Agustus 2018.

\section{Penyajian Data}

Karakteristik identitas responden adalah profile terhadap objek penelitian yang dapat memberikan interprestasi terhadap hasil penelitian mengenai-faktor faktor yang mempengaruhi pelatihan dan promosi jabatan terhadap kinerja karyawan. Dimana untuk mengimplementasikan hal tersebut, maka responden dalam penelitian ini adalah karyawan outsourcing pada PT Garuda Indonesia yang telah ditetapkan yakni sebanyak 59 responden dengan melakukan penyebaran koesioner secara propability sampling, yaitu teknik pengambilan sample yang memberikan peluang yang sama 
bagi setiap anggota populasi untuk dipilih menjadi anggota sampel.

\section{HASIL PENELITIAN DAN PEMBAHASAN}

Adapun persepsi dari setiap penelitian, akan dibahas sesuai dengan tahapan-tahapan analisis data berdasarkan hasil kuesioner penelitian yang terdiri dari 3 jenis kuesioner yaitu dua kuesioner variabel bebas (XI dan X2) dari variabel terikat (Y), untuk kuesioner pelatihan (XI) memuat 10 pernyataan sedangkan promosi jabatan $(X 2)$ memuat 10 pernyataan dan kinerja karyawan $(Y)$ memuat 10 pernyataan, dimana semua kuesioner berjumlah 30 pernyataan yang dikumpulkan dari 59 responden.

\section{Uji Reliabilitas}

Dalam melakukan pengujian reliabilitas instrumen, penulis menggunakan bantuan program SPSS versi 23. Reliabilitas instrumen merupakan sayarat untuk pengujian validitas instrumen. Oleh sebab itu, meskipunpun instrumen yang valid umumnya reliabel, tetapi pengujian reliabilitas instrumen perlu dilakukan. Pengambilan keputusan reliabilitas suatu variabel ditentukan dengan membandingkan nilai 0,6 apabila nilai Cronbach's alpha $>0,6$ maka dapat dikatakan bahwa suatu variabel adalah reliable. Hasil pengujian dan intepretasi reliabilitas variabel pelatihan, promosi jabatan dan kinerja karyawan seluruhnya telah dirangkum dalam tabel $\mathrm{I}$.

Tabel I.Hasil Uji Realibilitas Instrumen Penelitian

\begin{tabular}{|c|c|c|c|}
\hline Variabel & $\begin{array}{c}\text { Cronbach } \\
\text { alpha }\end{array}$ & $\begin{array}{c}\text { Cronbach } \\
\text { alpha Yang } \\
\text { disarankan }\end{array}$ & Keterangan \\
\hline Pelatihan & 0,734 & 0,600 & Reliable \\
\hline Promosi Jabatan & 0,678 & 0,600 & Reliable \\
\hline Kinerja Karyawan & 0,719 & 0,600 & Reliable \\
\hline Sumber : Hasil Pengolahan Data SPSS 23
\end{tabular}

\section{Analisis Regresi Sederhana dan}

\section{Berganda}

a. Analisis Regresi Sederhana

I) Koefisien Regresi Sederhana Pelatihan $\left(X_{1}\right)$ terhadap Kinerja Karyawan $(Y)$
Koefisien regresi sederhana dalam penelitian ini bertujuan untuk mengetahui bagaimana pengaruh yang terjadi pada kinerja karyawan apabila pelatihan mengalami perubahan.

Tabel 2.Koefisien Regresi Sederhana $X, Y$ Coefficients ${ }^{a}$

\begin{tabular}{|c|c|c|c|c|c|}
\hline \multirow{2}{*}{ Model } & \multicolumn{2}{|c|}{ Unstandardized Coefficients } & $\begin{array}{l}\text { Standardized } \\
\text { Coefficients }\end{array}$ & \multirow{2}{*}{$\mathrm{t}$} & \multirow{2}{*}{ Sig. } \\
\hline & B & Std. Error & Beta & & \\
\hline I (Constant) & 21.784 & 4.674 & & 4.661 & .000 \\
\hline PELATIHAN & .470 & - 116 & .473 & 4.054 & .000 \\
\hline
\end{tabular}

a. Dependent Variable: Kinerja Karyawan

Sumber : Hasil Pengelolaan Data SPSS 23

Berdasarkan tabel diatas dapat diketahui bahwa koefisien regresi sederhana yang didapat adalah $\mathrm{Y}=$ $21,784+0,470 X_{1}$. Penjelasan persamaan tersebut adalah sebagai berikut :

a) Konstanta sebesar 21,784 artinya jika pelatihan nilainya 0 , maka 
tingkat kinerja karyawan nilainya sebesar 21,784

b) Hasil analisis regresi sederhana pada tabel diatas diperoleh koefisien untuk pelatihan $\left(X_{1}\right)=$ 0,470 dengan konstanta sebesar 21,784 sehingga model persamaan regresi diperoleh

$Y=21,784+0,470 X_{1}$ yang artinya apabila ada peningkatan pelatihan sebesar I poin, maka akan meningkatkan kinerja karyawan sebesar 0,470 poin.

2) Koefisien Regresi Sederhana Promosi Jabatan $\left(\mathrm{X}_{2}\right)$ terhadap Kinerja Karyawan (Y)

Hasil analisis koefisien regresi sederhana promosi jabatan terhadap kinerja karyawan telah diringkas dalam tabel berikut :

Tabel 3.Koefisien Regresi Sederhana $X_{2} Y$

Coefficients $^{\mathrm{a}}$

\begin{tabular}{|c|c|c|c|c|c|}
\hline \multirow[b]{2}{*}{ Model } & \multicolumn{2}{|c|}{$\begin{array}{c}\text { Unstandardized } \\
\text { Coefficients }\end{array}$} & \multirow{2}{*}{$\begin{array}{l}\text { Standardized } \\
\text { Coefficients } \\
\text { Beta }\end{array}$} & \multirow[b]{2}{*}{$\mathrm{T}$} & \multirow[b]{2}{*}{ Sig. } \\
\hline & $B$ & Std. Error & & & \\
\hline I (Constant) & 30.428 & 4.574 & & 6.653 & .000 \\
\hline $\begin{array}{l}\text { PROMOSI } \\
\text { JABATAN }\end{array}$ & .246 & .110 & .285 & 2.247 & .029 \\
\hline
\end{tabular}

a. Dependent Variable: Kinerja Karyawan

Sumber : Hasil Pengelolaan Data SPSS 23

Berdasarkan pada tabel diatas dapat diketahui bahwa koefisien regresi sederhana yang didapat adalah $\mathrm{Y}=30,428+0,246 \mathrm{X}_{2}$. Penjelasan persamaan tersebut adalah sebagai berikut :

a) Konstanta sebesar 30,428 artinya jika promosi jabatan nilainya 0 , maka tingkat Kinerja Karyawan nilainya sebesar 30,428

b) Hasil analisis regresi sederhana pada tabel diatas diperoleh koefisien untuk promosi jabatan $\left(X_{2}\right)=0,246$ dengan konstanta sebesar 30,428 sehingga model persamaan regresi diperoleh $Y=30,428+0,246 X_{2}$ yang artinya apabila ada peningkatan promosi jabatan sebesar I poin, maka akan meningkatkan kinerja karyawan sebesar 0,246 poin.

b. Analisis Regresi Berganda $\left(X_{1}\right),\left(X_{2}\right)$ dengan ( $Y$ )

Koefisien regresi berganda dalam penelitian ini bertujuan untuk mengetahui bagaimana pengaruh yang terjadi pada kinerja karyawan apabila pelatihan dan promosi jabatan mengalami perubahan

Tabel 4.Koefisien Regresi Berganda $X_{1} X_{2} Y$

Coefficients $^{\mathrm{a}}$

\begin{tabular}{|rl|r|r|r|r|r|}
\hline \multirow{2}{*}{ Model } & \multicolumn{2}{|c|}{$\begin{array}{c}\text { Unstandardized } \\
\text { Coefficients }\end{array}$} & $\begin{array}{c}\text { Standardized } \\
\text { Coefficients }\end{array}$ & \multirow{2}{*}{ T } & \multirow{2}{*}{ Sig. } \\
\cline { 2 - 5 } & \multicolumn{1}{|c|}{ B } & Std. Error & \multicolumn{1}{|c|}{ Beta } & & \\
\hline I & (Constant) & 20.579 & 5.199 & & 3.958 & .000 \\
& PELATIHAN & .435 & .133 & .438 & 3.259 & .002 \\
& PROMOSI JABATAN & .063 & .116 & .073 & .544 & .589 \\
\hline
\end{tabular}

a. Dependent Variable: KINERJA KARYAWAN 
Berdasarkan hasil analisis regresi linear berganda pada tabel diatas diperoleh koefisien untuk variabel bebas $X_{1}=0,435$ $X_{2}=0,063$ dengan konstanta sebesar 20,579 sehingga model persamaan regresi diperoleh $Y=$ $20,579+0,435 X_{1}+0,063 X_{2}$. Artinya, apabila pelatihan meningkat sebesar I poin dengan asumsi promosi jabatan tidak berubah, maka kinerja karyawan akan meningkat sebesar 0,435 poin. Selanjutnya

\section{Analisis Korelasi Sederhana dan Berganda}

Nilai koefisien korelasi bertujuan untuk mengetahui tingkat kekuatan hubungan variabel bebas dengan variabel terikat. Sedangkan nilai koefisien determinasi apabila promosi jabatan meningkat sebesar I poin dengan asumsi pelatihan tidak berubah, maka kinerja karyawan akan meningkat sebesar 0,063 poin. Sebaliknya apabila terjadi penurunan pada pelatihan dan promosi jabatan, maka kinerja karyawan juga akan ikut mengalami penurunan. Pengaruh yang demikian disebut dengan pengaruh yang searah.

digunakan untuk mengetahui besaran persentase kontribusi variabel bebas terhadap perubahan yang terjadi pada variabel terikat. Menurut Sugiyono (2016:184), pedoman untuk memberikan interpretasi koefisien korelasi ada dalam tabel 5 dibawah ini:

Tabel 5. Nilai Korelasi

\begin{tabular}{|c|c|}
\hline 0,00 hingga 0,199 & sangat rendah \\
\hline 0,20 hingga 0,399 & Rendah \\
\hline 0,40 hingga 0,599 & Sedang \\
\hline 0,60 hingga 0,799 & Kuat \\
\hline 0,80 hingga 1,000 & sangat kuat \\
\hline
\end{tabular}

a. Analisis Korelasi Sederhana

I) Koefisien Korelasi Variabel Pelatihan $\left(X_{I}\right)$ terhadap Kinerja Karyawan $(Y)$
Hasil pengelolaan data menggunakan metode komputerisasi program SPSS 23, hasil perhitungan koefisien korelasi dirangkum dalam tabel berikut :

Tabel 6. Korelasi Sederhana $X_{1} Y$

Model Summary

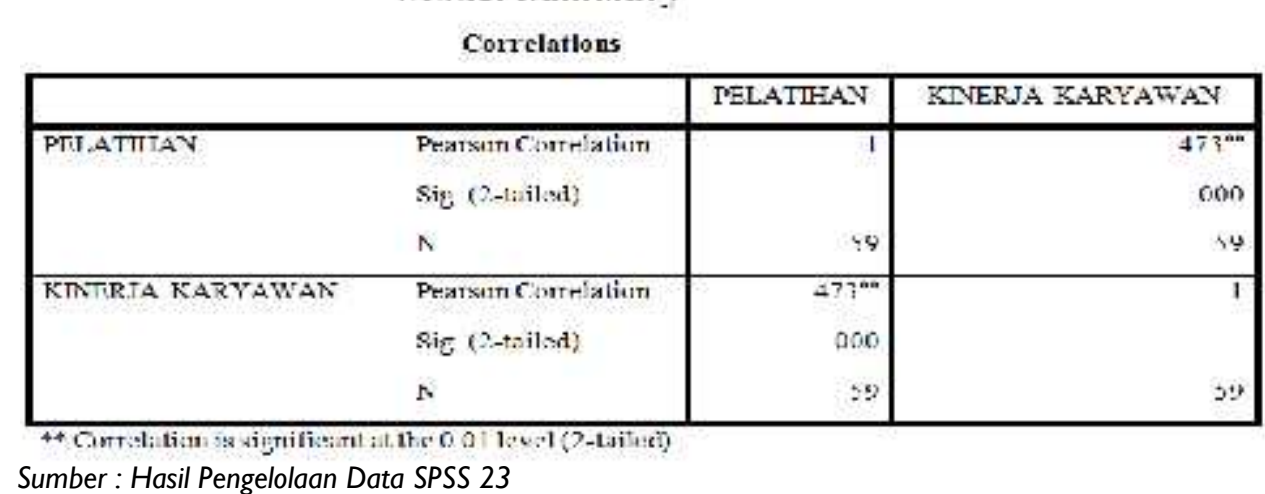

Berdasarkan Tabel 6 diatas, dapat diketahui bahwa koefisien korelasi variabel pelatihan dengan kinerja adalah sebesar 0,473. Berdasarkan 
tabel pedoman penentuan interpretasi yang dikemukakan oleh Sugiyono, maka hubungan antara variabel pelatihan terhadap kinerja karyawan dalam penelitian ini termasuk dalam kategori sedang.
2) Koefisien Korelasi Variabel Promosi Jabatan $\left(\mathrm{X}_{2}\right)$ terhadap Kinerja Karyawan (Y)

Hasil perhitungan korelasi Promosi Jabatan dengan Kinerja Karyawan telah dirangkum dalam tabel berikut :

Tabel 7. Korelasi Sederhana $X_{2} Y$

\begin{tabular}{|c|c|c|c|}
\hline \multicolumn{4}{|c|}{$\begin{array}{c}\text { Model Sumbiary } \\
\text { Carrolations }\end{array}$} \\
\hline & & $\begin{array}{l}\text { TROMLSI } \\
\text { TARTAN }\end{array}$ & $\begin{array}{l}\text { KINLKIA } \\
\text { KARYAWAR }\end{array}$ \\
\hline TROMESH AABATAN & $\begin{array}{l}\text { Dharson finitalation } \\
\text { Sig. (2 loited) } \\
\text { K }\end{array}$ & $\begin{array}{r}1 \\
30\end{array}$ & $\begin{array}{r}2851 \\
029 \\
50\end{array}$ \\
\hline FINLRA KARYAWAN & $\begin{array}{l}\text { Pearsou Cunnelation } \\
\mathrm{S}_{\mathrm{n}} \text { C-tailod } \\
\Omega\end{array}$ & $\begin{array}{r}283^{4} \\
0 \% 5 \\
3\end{array}$ & $\begin{array}{l}1 \\
20\end{array}$ \\
\hline
\end{tabular}

Berdasarkan Tabel 7 diatas, dapat diketahui bahwa koefisien korelasi variabel promosi jabatan dengan kinerja adalah sebesar 0,285. Berdasarkan tabel pedoman penentuan interpretasi yang dikemukakan oleh Sugiyono, maka hubungan antara variabel promosi jabatan terhadap kinerja karyawan dalam penelitian ini termasuk dalam kategori rendah.

b. Analisis Korelasi Berganda

Nilai koefisien korelasi berganda bertujuan untuk mengetahui tingkat kekuatan hubungan dua variabel bebas atau lebih dengan variabel terikat secara bersama-sama. Hasil perhitungan korelasi berganda telah dirangkum dalam tabel berikut.

Tabel 8. Korelasi Berganda $X_{1} X_{2} Y$

Model Summary

\begin{tabular}{|l|r|r|r|r|}
\hline Model & $R$ & R Square & Adjusted R Square & Std. Error of the Estimate \\
\hline $\mathrm{I}$ & $.477^{\mathrm{a}}$ & .228 & .200 & 3.06479 \\
\hline
\end{tabular}

a. Predictors: (Constant), PROMOSI JABATAN, PELATIHAN

Sumber : Hasil Pengelolaan Data SPSS 23

Bedasarkan Tabel 8 diatas, dapat diketahui bahwa koefisien korelasi berganda variabel pelatihan dan promosi jabatan dengan kinerja karyawan adalah

\section{Uji Koefisien Determinasi (KD)}

Uji KD digunakan untuk mengetahui seberapa jauh variabel bebas dapat sebesar 0,477. Dapat diketahui bahwa hubungan antara pelatihan dan promosi jabatan terhadap kinerja karyawan mempunyai tingkat hubungan sedang. menjelaskan variabel terikat, maka perlu diketahui nilai koefisien determinasinya. 
Rumus untuk mencari nilai koefisien determinasi adalah sebagai berikut :

$$
K D=(r)^{2} \times 100 \%
$$

a. Koefisien Determinasi Pelatihan $\left(X_{1}\right)$ terhadap Kinerja Karyawan (Y) Berdasarkan perhitungan SPSS, maka hasil perhitungan dapat dilihat pada tabel berikut :

Tabel 9. Koefisien Determinasi $X, Y$

Model Summary

\begin{tabular}{|c|c|c|c|c|}
\hline Model & $\mathrm{R}$ & R Square & Adjusted R Square & $\begin{array}{l}\text { Std. Error of the } \\
\text { Estimate }\end{array}$ \\
\hline $\mathrm{I}$ & $.473^{a}$ & .224 & .210 & 3.04580 \\
\hline
\end{tabular}

Berdasarkan tabel 9 angka koefisien determinasi yang didapat adalah sebesar 0,224 . Angka tersebut apabila dikalikan dengan 100\% maka hasil yang didapat adalah sebesar 22,40\%. Artinya, kontribusi yang diberikan pelatihan terhadap kinerja karyawan adalah sebesar $22,40 \%$, sedangkan sisanya sebesar
$77,60 \%$ ditentukan oleh variabel lain yang tidak diteliti.

b. Koefisien Determinasi Promosi Jabatan $\left(\mathrm{X}_{2}\right)$ terhadap Kinerja Karyawan ( $\mathrm{Y}$ ) Berdasarkan perhitungan SPSS, maka hasil perhitungan dapat dilihat pada tabel berikut :

Tabel 10. Koefisien Determinasi $X_{2} Y$

Model Summary

\begin{tabular}{|l|r|r|r|r|}
\hline Model & $\mathrm{R}$ & R Square & Adjusted R Square & $\begin{array}{c}\text { Std. Error of the } \\
\text { Estimate }\end{array}$ \\
\hline $\mathrm{I}$ & $.285^{\mathrm{a}}$ & $.08 \mathrm{I}$ & .065 & 3.31338 \\
\hline
\end{tabular}

a. Predictors: (Constant), PROMOSI JABATAN

Sumber : Hasil Pengelolaan Data SPSS 23

Berdasarkan tabel 10 angka koefisien determinasi yang didapat adalah sebesar 0,08 I. Angka tersebut apabila dikalikan dengan 100\% maka hasil yang didapat adalah sebesar 08,10\%. Artinya, kontribusi yang diberikan promosi jabatan terhadap kinerja karyawan adalah sebesar $08,10 \%$, sedangkan sisanya sebesar
91,90\% ditentukan oleh variabel lain yang tidak diteliti.

c. Koefisien Determinasi Pelatihan (XI) dan Promosi Jabatan (X2) terhadap Kinerja Karyawan (Y)

Berdasarkan perhitungan SPSS, maka hasil perhitungan dapat dilihat pada tabel berikut :

Tabel I I. Koefisien Determinasi $X_{1} X_{2} Y$

Model Summary

\begin{tabular}{|c|r|r|r|r|}
\hline Model & R & R Square & Adjusted R Square & $\begin{array}{c}\text { Std. Error of the } \\
\text { Estimate }\end{array}$ \\
\hline I & $.477 \mathrm{a}$ & .228 & .200 & 3.06479 \\
\hline
\end{tabular}

Berdasarkan tabel II angka koefisien determinasi yang didapat adalah sebesar 0,228 . angka tersebut apabila dikalikan dengan 100\% maka hasil yang didapat adalah sebesar 22,80\%. Artinya, kontribusi yang diberikan pelatihan dan promosi jabatan terhadap perubahan yang terjadi pada kinerja karyawan adalah 
sebesar $22,80 \%$, sedangkan sisanya sebesar $77,20 \%$ ditentukan oleh variabel lain yang tidak diteliti.

\section{Uji Hipotesis}

a. Uji Parsial ( $t)$

Uji $t$ bertujuan untuk menguji pengaruh signifikan secara parsial yang diberikan oleh pelatihan terhadap kinerja karyawan. Pengujian menggunakan uji $t$ dua sisi dengan $\alpha$ sebesar $5 \%$.

I) Uji Hipotesis I

Hasil perhitungan nilai $t$ hitung dapat dilihat pada tabel output SPSS dibawah ini :

Tabel I2. Uji t $\mathbf{X}, \mathbf{Y}$

Coefficients $^{a}$

\begin{tabular}{|c|c|c|c|c|c|}
\hline \multirow[t]{2}{*}{ Model } & \multicolumn{2}{|c|}{ Unstandardized Coefficients } & $\begin{array}{l}\text { Standardized } \\
\text { Coefficients }\end{array}$ & \multirow[t]{2}{*}{$\mathrm{t}$} & \multirow[t]{2}{*}{ Sig. } \\
\hline & $B$ & Std. Error & Beta & & \\
\hline (Constant) & 21.784 & 4.674 & & 4.661 & .000 \\
\hline PELATIHAN & .470 & .116 & .473 & 4.054 & .000 \\
\hline
\end{tabular}

a. Dependent Variable: Kinerja Karyawan

Sumber : Hasil Pengelolahan Data SPSS 23

Kriteria uji t dua sisi dilakukan dengan membandingkan nilai $\mathrm{t}$ hitung dengan nilai $t$ tabel. Berdasarkan tabel 4.2I, nilai $\mathrm{t}$ hitung yang didapat adalah sebesar 4,054, sedangkan nilai $t$ tabel dengan $\alpha=5 \%$ dan nilai df (derajat bebas) $=\mathrm{n}-\mathrm{k}-\mathrm{I}=59-2-\mathrm{I}$, dimana $k$ adalah jumlah seluruh variabel bebas yang diuji adalah sebesar 2,002.

Langkah pengujian hipotesis adalah sebagai berikut :

a) Hipotesis dalam bentuk kalimat.

Hipotesis $\quad \begin{gathered}\text { I:Diduga pelatihan } \\ \text { berpengaruh } \\ \text { terhadap } \\ \text { kinerjakaryawan. }\end{gathered}$

b) Hipotesis dalam bentuk statistik.

$\mathrm{H}_{\circ}: \rho=0$, tidak terdapat pengaruh.

$\mathrm{H}_{\mathrm{a}}: \rho \neq 0$, terdapat pengaruh. c) Membandingkan nilai $t$ hitung dengan nilai $t$ tabel.

Pengujian dilakukan dengan menggunakan uji 2 sisi dengan cara membandingkan nilai $t$ hitung dengan nilai $t$ tabel.

d) Membuat keputusan.

Dapat diketahui bahwa $\mathrm{t}$ hitung $>\mathrm{t}$ tabel atau 4,054 $>2,002$. Nilai $t$ hitung tersebut berada pada daerah penolakan $\mathrm{H}_{0}$. Maka hasil pengujian menyatakan $\mathrm{H}_{\circ}$ ditolak dan $\mathrm{H}_{\mathrm{a}}$ diterima.

Artinya, pelatihan berpengaruh secara signifikan pada kinerja karyawan Outsourcing di PT Garuda Indonesia.

2) Uji hipotesis 2

Dari hasil perhitungan nilai $t$ hitung dapat dilihat pada tabel 13 output SPSS dibawah ini :

Tabel 13. Uji t $\mathbf{X}_{2} \mathbf{Y}$

Coefficients ${ }^{\mathrm{a}}$

\begin{tabular}{|c|c|c|c|c|c|}
\hline \multirow{2}{*}{ Model } & \multicolumn{2}{|c|}{ Unstandardized Coefficients } & $\begin{array}{l}\text { Standardized } \\
\text { Coefficients }\end{array}$ & \multirow[t]{2}{*}{$\mathrm{T}$} & \multirow{2}{*}{ Sig. } \\
\hline & $B$ & Std. Error & Beta & & \\
\hline (Constant) & 30.428 & 4.574 & & 6.653 & .000 \\
\hline $\begin{array}{l}\text { PROMOSI } \\
\text { JABATAN }\end{array}$ & .246 & .110 & .285 & 2.247 & .029 \\
\hline
\end{tabular}


Langkah pengujian hipotesis adalah sebagai berikut :

a) Hipotesis dalam bentuk kalimat.

Hipotesis 2 : Diduga promosi

jabatan

berpengaruh

terhadap kinerja

karyawan

b) Hipotesis dalam bentuk statistik. $\mathrm{H}_{\mathrm{o}}: \rho=0$, tidak terdapat pengaruh. $H_{a}: \rho \neq 0$, terdapat pengaruh.

c) Membandingkan nilai $t$ hitung dengan nilai $t$ tabel.

Pengujian dilakukan dengan menggunakan uji 2 sisi dengan cara membandingkan nilai $t$ hitung dengan nilai t tabel. Dapat diketahui bahwa t hitung $>\mathrm{t}$ tabel atau 2,247 $>2,002$. Nilai $t$ hitung tersebut berada pada daerah penolakan Ho. Maka hasil pengujian menyatakan $\mathrm{H}_{\mathrm{o}}$ ditolak dan $\mathrm{H}_{\mathrm{a}}$ diterima. Artinya, promosi jabatan berpengaruh secara signifikan terhadap kinerja karyawan outsourcing di PT Garuda Indonesia.

b. Uji Simultan (F)

Uji $F$ bertujuan untuk menguji pengaruh signifikan secara simultan yang diberikan oleh pelatihan dan promosi jabatan terhadap kinerja karyawan. Pengujian menggunakan uji $F$ dengan $\alpha$ sebesar $5 \%$.

Tabel I4. Uji F $X_{1} X_{2} Y$

svovi.

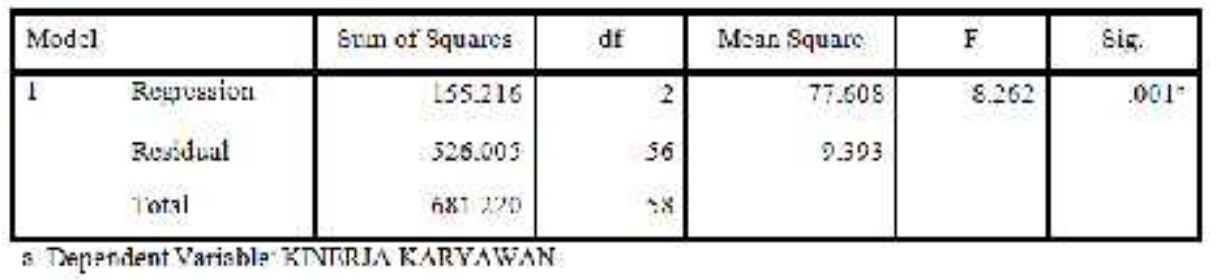

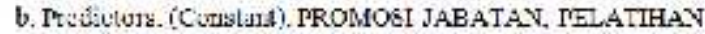

Sumber : Hasil Pengelolahan Data SPSS 23

Kriteria uji $f$ dilakukan dengan membandingkan nilai $F$ hitung dengan nilai $\mathrm{F}$ tabel. Berdasarkan tabel 14 , nilai $\mathrm{F}$ hitung yang didapat adalah sebesar 8,262. Sedangkan nilai $\mathrm{F}$ tabel dengan $\alpha$ sebesar $5 \%$ dapat diperoleh dengan menentukan nilai df yaitu $n-k-l$, dimana $k$ adalah jumlah seluruh variabel bebas yang diteliti, maka $n-k-1=59-2-1=56$. Maka, nilai $\mathrm{F}$ tabel yang diperoleh adalah 3,16.

Langkah pengujian hipotesis adalah sebagai berikut :

Hipotesis dalam bentuk kalimat.

Hipotesis : diduga pelatihan dan promosi jabatan secara simultan (bersama-sama) memiliki pengaruh yang signifikan terhadap kinerja karyawan outsourcing di PT Garuda Indonesia.

I) Hipotesis dalam bentuk statistik.
$\mathrm{H}_{\circ}$ : $\mathrm{F}$ hitung $<\mathrm{F}$ tabel $=0$, tidak terdapat pengaruh.

$\mathrm{H}_{\mathrm{a}}$ : $\mathrm{F}$ hitung $>\mathrm{F}$ tabel $\neq 0$, terdapat pengaruh.

2) Membandingkan nilai $F$ hitung dengan nilai $\mathrm{F}$ tabel.

Nilai $F$ hitung yang di peroleh adalah sebesar 8,262, sedangkan nilai $F$ tabel diperoleh sebesar 3,16. Maka, dapat diketahui bahwa nilai $\mathrm{F}$ hitung $>\mathrm{F}$ tabel $(8,262>3,16)$.

3) Membuat keputusan.

Karena $\mathrm{F}$ hitung $>$ dari $\mathrm{F}$ tabel, maka hasil pengujian menyatakan Ho ditolak dan $\mathrm{Ha}$ diterima. Artinya, pelatihan dan promosi jabatan secara bersamasama berpengaruh signifikan terhadap kinerja karyawan outsourcing di PT Garuda Indonesia.

\section{Interprestasi Hasil}


Berdasarkan data penelitian yang telah dianalisis maka dapat dilakukan pembahasan hasil penelitian sebagai berikut:

Pengaruh yang diberikan kedua variabel bebas tersebut bersifat positif artinya semakin tinggi pelatihan dan promosi jabatan maka mengakibatkan semakin tinggi pula kinerja karyawan yang dihasilkan. Hasil tersebut sesuai dengan hipotesis yang diajukan. Penjelasan dari masing-masing pengaruh variabel dijelaskan sebagai berikut:

a. Pengaruh Variabel Pelatihan $\left(X_{1}\right)$ terhadap Kinerja Karyawan (Y)

Pelatihan sebagai proses untuk membentuk dan membekali karyawan dengan menambah keahlian, kemampuan dan keterampilan yang dimilikinya. Melalui pelatihan diharapkan karyawan dapat menambah pengetahuan yang dimilikinya serta untuk mengasah kemampuannya yang selama ini kurang optimal ataupun belum ada sama sekali. Dalam praktiknya banyak karyawan yang memiliki kemampuan yang cukup besar tetapi belum dioptimalkan. Dengan mengikuti pelatihan, pengetahun dan keahlian yang dimiliki oleh karyawan yang telah mengikuti pelatihan akan bertambah. Hal ini akan terlihat dari hasil kinerja yang dicapainya pada saat bekerja. Hasil pengujian hipotesis $\left(H_{I}\right)$ secara parsial telah membuktikan terdapat pengaruh antara pelatihan terhadap kinerja karyawan. Melalui hasil perhitungan yang telah dilakukan didapat nilai $t$ hitung sebesar 4,054 nilai tersebut lebih besar dari $t$ tabel 2,002 yang berarti bahwa hipotesis dalam penelitian ini menolak $\mathrm{H}_{\circ}$ dan menerima $H_{a}$, Pengujian ini secara statistik membuktikan bahwa pelatihan berpengaruh signifikan terhadap kinerja karyawan. Artinya bahwa ada pengaruh antara variabel pelatihan terhadap kinerja karyawan outsourcing di PT Garuda Indonesia.

b. Pengaruh Variabel Promosi Jabatan $\left(\mathrm{X}_{2}\right)$ terhadap Kinerja Karyawan ( $Y$ )

Perusahaan membutuhkan karyawan yang berkinerja tinggi, pada saat yang sama karyawan memerlukan umpan balik atas kinerja mereka. Untuk meningkatkan kinerja karyawan tidaklah mudah, maka dari itu perlu adanya motivasi karyawan dengan cara pengembangan karir yang salah satunya dengan melakukan promosi jabatan. Promosi jabatan akan memberikan peran penting bagi karyawan, bahkan menjadi idaman atau keinginan yang selalu dinanti-nantikan oleh setiap karyawan. Adanya promosi, akan menunjukkan ada kepercayaan dan pengakuan mengenai kemampuan serta kecakapan karyawan yang bersangkutan. Jika karyawan dipromosikan berdasarkan asas keadilan dan objektivitas, karyawan akan terdorong untuk bekerja lebih giat, bersemangat, disiplin dan berprestasi kerja sehingga sasaran perusahaan secara optimal dapat tercapai. Hasil pengujian hipotesis $\left(\mathrm{H}_{2}\right)$ secara parsial telah membuktikan terdapat pengaruh antara promosi jabatan terhadap kinerja karyawan. Melalui hasil perhitungan yang telah dilakukan didapat nilai $t$ hitung sebesar 2,247, nilai tersebut lebih besar dari $t$ tabel 2,002 yang berarti bahwa hipotesis dalam penelitian ini menolak $\mathrm{H}_{\circ}$ dan menerima $H_{a}$, Pengujian ini secara statistik membuktikan bahwa promosi jabatan berpengaruh signifikan terhadap kinerja karyawan. Artinya bahwa ada pengaruh antara variabel promosi jabatan terhadap kinerja karyawan outsourcing di PT Garuda Indonesia.

c. Pengaruh Variabel Pelatihan $\left(X_{1}\right)$ dan Promosi Jabatan $\left(\mathrm{X}_{2}\right)$ terhadap Kinerja Karyawan (Y)

Kinerja merupakan gambaran dari hasil kerja secara kualitas dan kuantitas yang dicapai oleh seorang karyawan dalam melaksanakan pekerjaannya. Antara karyawan dengan perusahaan harus memiliki hubungan timbal balik yang saling menguntungkan satu sama lain. Karyawan melaksanakan kewajiban nya dengan cara menyelesaikan pekerjaan yang diberikan kepadanya. Perusahaan memberikan hak kepada karyawannya atas kewajiban yang telah diselesaikannya. Untuk membantu karyawan mengembangkan kemampuan atau potensi dan mencapai karir yang diinginkan maka perusahaan mengadakan program pelatihan pegawai yang dapat meningkatkan kinerja karyawan, sehingga perusahaan dapat memberikan apresiasi dan penghargaan kepada karyawan yang 
berkinerja baik berupa pemberian promosi jabatan. Hasil pengujian hipotesis $\left(\mathrm{H}_{3}\right)$ telah membuktikan terdapat pengaruh antara pelatihan dan promosi jabatan terhadap kinerja karyawan. Melalui hasil perhitungan yang telah dilakukan didapat nilai $f$ hitung sebesar 8,262 yang lebih besar dari nilai $F$ tabel 3,16 yang berarti bahwa hipotesis dalam penelitian ini menolak $\mathrm{H}_{\circ}$ dan menerima $\mathrm{H}_{\mathrm{a}}$, Pengujian ini secara statistik membuktikan bahwa pelatihan dan promosi jabatan secara simultan berpengaruh signifikan terhadap kinerja karyawan outsourcing di PT Garuda Indonesia.

\section{DAFTAR PUSTAKA}

Agusta, L dan Sutanto. E. M. 2013. Pengaruh Pelatihan dan Motivasi Kerja Terhadap Kinerja Karyawan. Surabaya : CV Haragon.

Anaviyah, Vivi. 2015. Pengaruh Pelatihan Pegawai dan Promosi Jabatan Terhadap Kinerja Pegawai Pada Bagian Tata Usaha Pusat Sumber Daya Air Tanah dan Geologi Lingkungan Bandung.

Ardana, I Komang dkk. 20I2. Manajemen Sumber Daya Manusia. Yogyakarta: Garaha Ilmu.

Eko, Widodo Suparno. 20I5. Manajemen Pengembangan Sumber Daya Manusia. Yogyakarta : Pustaka Pelajar.

Kasmir. 2016. Manajemen Sumber Daya Manusia (teori dan praktik). Depok : Raja Grafindo Persada.

Lestari, Lia. 2016. Pengaruh Pelatihan dan Motivasi Terhadap Kinerja karyawan Kampoeng Djowo Sekatul.

Mangkunegara, Anwar Prabu. 2013. Manajemen Sumber Daya Perusahaan. Bandung : Remaja Rosda Karya.

Moeheriono. 2012. Pengukuran Kinerja Berbasis Kompetensi. Jakarta : Raja Grafindo Persada.

Nursanti, Aldila. 2014. Pengaruh Pelatihan Kerja dan Pemberian Insentif Terhadap Kinerja Karyawan CV Kedai Digital Yogyakarta.

P. Siagian, Sondang. 20I4. Manajemen Sumber Daya Manusia. Jakarta : Bumi Aksara.

Rivai, Veithzal dan Ella Jauvani Sugala. 20I3. Manajemen Sumber Daya Manusia Untuk
Perusahaan Dari Teori ke Praktik. Jakarta : Raja Grafindo Persada.

Sabar, Navrathin Datu, Adolfina, Lucky O. H. Dotulong. 2017. Pengaruh Promosi Jabatan dan Mutasi Terhadap Kinerja Pegawai Direktoral Jenderal Perbendaharaan Sulawesi Utara

Sudaryono. 2017. Pengantar Manajemen Teori dan Kasus. Jakarta : Buku Seru.

Sugiyono. 2016. Metode Penelitian Kuantitatif, Kualitatif dan R\&D. Bandung : Alfabeta.

Supomo, R dan Eti Nurhayati. 2018. Manajemen Sumber Daya Manusia Untuk Mahasiswa \& Umum. Bandung : Yrama Widya. 